\title{
EVALUATION OF THE RIVAROXABAN-INFLUENCED EFFECT OF ABCB1 AND CYP3A5 GENE POLYMORPHISMS ON PROTHROMBIN TIME IN PATIENTS AFTER TOTAL HIP OR KNEE REPLACEMENT SURGERY
}

\author{
Sychev DA', Minnigulov RM²凶, Ryzhikova KA', Yudina IYu², Lychagin AV², Morozova TE² \\ ${ }^{1}$ Russian Medical Academy of Continuous Professional Education, Moscow \\ 2 Sechenov First Moscow State Medical University (Sechenov University), Moscow
}

\begin{abstract}
Rivaroxaban is a safer and more effective alternative to warfarin. However, there are reports of some cases of major hemorrhagic complications associated with rivaroxaban that significantly impair the patients' quality of life and can lead to a fatality. Personalized therapy, including pharmacogenetic testing, may help prevent such adverse events. This study aimed to investigate how $A B C B 1$ 3435C > T (rs1045642) and CYP3A5 6986A>G (rs776746) gene polymorphisms, when carried by a patient taking rivaroxaban to prevent thrombosis after total hip or knee replacement surgery, affect prothrombin time (PT). Sixty-five patients participated in the study. Their genotypes were identified by PCR in real time. To learn PT peculiar to each patient, we collected venous blood on the $5^{\text {th }}$ day of their anticoagulation therapy, 1 hour before they took rivaroxaban and 3 hours after. Having calculated \% $\triangle \mathrm{PT}$, we divided the patients into 2 groups: 1$) \% \Delta P T \leq 0$ ( $n=7 ; 10.8 \%) ; 2) \% \triangle P T>0(n=58 ; 89.2 \%)$. Regarding the distribution of rs1045642 polymorphism, we determined the difference between the groups to be statistically significant $\left(\chi^{2}=6.64 ; p=0.027\right)$. As for rs776746 polymorphism, the difference was insignificant $\left(\chi^{2}=0.101 ; p=1\right.$.0). We discovered that rs1045642 polymorphism has a significant effect on PT variance in patients taking rivaroxaban to prevent thrombosis after total hip or knee replacement surgery.
\end{abstract}

Keywords: rivaroxaban, pharmacogenetics, prothrombin time, hip replacement surgery, knee replacement surgery, thromboprophylaxis

Funding: this study was supported by Russian Science Foundation, project 16-15-00227 "Conducting fundamental scientific research and exploratory research on priority thematic research areas".

Acknowledgments: the authors would like to thank M. M. Bogdanov, practitioner with the Clinic of Traumatology, Orthopedics and Joint Pathology of the 1st Hospital of I. M. Sechenov First Moscow State Medical University, for his assistance in enlisting patients.

$\square$ Correspondence should be addressed: Radik M. Minnigulov

Bolshaya Pirogovskaya 2, bldg. 4, Moscow, 119435; radik.minnigulov@gmail.com

Received: 08.10.2018 Accepted: 30.10.2018

DOI: 10.24075/brsmu.2018.068

\section{ОЦЕНКА ВЛИЯНИЯ ПОЛИМОРФИЗМОВ ГЕНОВ АВСВ1 И СУРЗА5 НА СТЕПЕНЬ ИЗМЕНЕНИЯ ПРОТРОМБИНОВОГО ВРЕМЕНИ ПОД ВЛИЯНИЕМ РИВАРОКСАБАНА У ПАЦИЕНТОВ ПОСЛЕ ЭНДОПРОТЕЗИРОВАНИЯ КРУПНЫХ СУСТАВОВ НИЖНИХ КОНЕЧНОСТЕЙ}

\author{
Д. А. Сычев ${ }^{1}$, Р. М. Миннигулов ${ }^{2}$, К. А. Рыжикова ${ }^{1}$, И. Ю. Юдина², А. В. Лычагин², Т. Е. Морозова² \\ ${ }_{1}^{1}$ Российская медицинская академия непрерывного профессионального образования, Москва \\ ${ }^{2}$ Первый Московский государственный медицинский университет имени И. М. Сеченова (Сеченовский университет), Москва
}

\begin{abstract}
Несмотря на высокую эффективность и безопасность применения ривароксабана по сравнению с варфарином, в клинической практике наблюдаются редкие случаи крупных геморрагических осложнений, которые могут значительно ухудшать качество жизни пациентов или быть летальными. Остается открытым вопрос, насколько фармакогенетические тесты позволят профилактировать развитие таких неблагоприятных событий. Целью работы было оценить влияние носительства полиморфизмов АВСВ1 3435C>T (rs1045642) и CYP3A5 6986A>G (rs776746) на изменение протромбинового времени (ПВ) у пациентов, принимающих для тромбопрофилактики ривароксабан после эндопротезирования крупных суставов нижних конечностей. В исследование были включены 65 пациентов. Генотипирование проводили с помощью ПЦР в реальном времени. Для определения ПВ венозную кровь отбирали на 5 сутки приема антикоагулянта 2 раза: за 1 ч до приема ривароксабана и через 3 ч после приема. Вычислив \% $\triangle$ п,

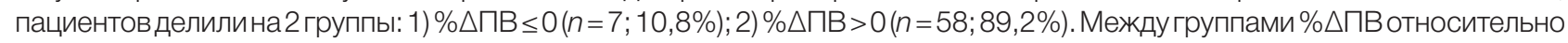
распределения генотипов полиморфизма rs1045642 была определена статистически достоверная разница $\left(\chi^{2}=6,64\right.$; $p=0,027)$. Относительно распределения генотипов полиморфизма rs776746 статистически значимой разницы между группами \% $\triangle$ ПВ обнаружено не было $\left(\chi^{2}=0,101 ; p=1,0\right)$. Выявлено статистически значимое влияние полиморфизма rs1045642 на характер изменения ПВ у пациентов, принимающих с целью тромбопросилактики ривароксабан после эндопротезирования крупных суставов нижних конечностей.
\end{abstract}

Ключевые слова: ривароксабан, фармакогенетика, протромбиновое время, эндопротезирование тазобедренного сустава, эндопротезирование коленного сустава, тромбопросилактика

Финансирование: работа выполнена при финансовой поддержке Российского научного фонда, проект 16-15-00227 «Проведение фундаментальных научных исследований и поисковых научных исследований по приоритетным тематическим направлениям исследований».

Благодарности: Богданову М. М., врачу клиники травматологии, ортопедии и патологии суставов УКБ №1 Первого МГМУ им. И. М. Сеченова за помощь в наборе пациентов.

$\bigotimes$ Для корреспонденции: Радик Мисхатович Миннигулов ул. Большая Пироговская, д. 2, стр. 4, г. Москва, 119435; radik.minnigulov@gmail.com

Статья получена: 08.10.2018 Статья принята к печати: 30.10.2018

DOI: $10.24075 /$ vrgmu.2018.068 
Deep vein thrombosis (DVT) and pulmonary embolism (PE) are some of the most important problems encountered by practitioners. PE risk group includes patients after hip or knee replacement surgery. About 50-60\% of THR (total hip replacement surgery) and TKR (total knee replacement surgery) patients that receive no thrombosis prevention therapy have DVT after surgery [1]. Approximately 1 in every 500 THR patients can have a fatal $P E$ [2]. The number of THRs in Russia is increasing every year; currently, about 25 persons in each 100,000 have THRs [3].

Direct oral anticoagulants (DOACs) have recently been approved for the prevention of venous thromboembolism (VTE) in patients after elective hip or knee arthroplasty. DOACs have demonstrated acceptable efficacy and safety profiles. These drugs require no laboratory control. This article focuses on rivaroxaban, which is a direct factor Xa inhibitor. The anticoagulant got the FDA approval in 2011 as a medication to prevent thrombosis in patients after elective hip or knee arthroplasty [4].

About $18 \%$ of the rivaroxaban dose is metabolized by CYP3A4/5, 14\% - by CYP2J2.

Approximately $36 \%$ of the dose is excreted via kidney in form of the unchanged drug, involving the active transportermediated secretion by P-glycoprotein (P-gp) and BCRP (Breast Cancer Resistance Protein) [5].

$\mathrm{P}$-gp is a large membrane protein that transports drugs from inside the cell. It is found on the surface of epithelial cells lining small and large intestines, pancreatic duct, in the liver's bile vessels membrane, proximal kidney tubules and adrenal glands, as well as in endothelial cells of blood-tissue interfaces (brain-blood, blood-follicle, blood-testis, and bloodplacental barriers) [6]. P-gp is encoded by the ABCB1 gene located on chromosome 7 (7q21.12) [7]. The most common single nucleotide polymorphisms (SNPS) of the ABCB1 gene are $1236 \mathrm{~T}>\mathrm{C}$ (rs1128503), 2677T> G / A (rs2032582) and $3435 T>C$ (rs1045642) [8]. In this study, we focused on the impact of the ABCB1 3435C>T polymorphism (rs1045642).

Jointly, CYP3A4 and CYP3A5 proteins account for about 30\% of hepatic cytochrome P450; about half of the drugs metabolized by cytochrome P450 are CYP3A substrates. CYP3A4 and CYP3A5 are expressed in liver and intestines, with CYP3A5 expression seen mostly in extrahepatic tissues. The CYP3A5 gene is located on chromosome 7 (7q22.1); it encodes the protein of 502 amino acids. The most common SNP of the CYP3A5 gene is 6986A>G (rs776746). It should be noted here that CYP3A5 6986GG genotype carriers do not fully express the CYP3A5 isoenzyme [9].

According to the RECORD 1-4 research program [10-13], despite the good efficacy and safety profiles of rivaroxaban when prescribed to prevent thrombosis after hip or knee replacement surgery, $2.87 \%$ of patients exhibited nonmajor clinically relevant bleeding, including hematomas in the area of surgery that may be infected. Such complications require removal of the endoprosthesis, which worsens the patient's quality of life and translates into an additional financial burden for the health care system. Currently, practitioners resort to the personalized therapy, including pharmacogenetic testing, to prevent such adverse events.

This study aimed to investigate how the ABCB1 3435C > T (rs1045642) and CYP3A5 6986A>G (rs776746) gene polymorphisms, when carried by a patient taking rivaroxaban to prevent thrombosis after total hip or knee replacement surgery, the affect prothrombin time (PT).

\section{METHODS}

The study protocol was reviewed and approved by the local ethics committee of I. M. Sechenov First Moscow State Medical
University (Sechenov University) (meeting minutes \#03-17 of 2017.04.19). The inclusion criteria were: any gender; age $\geq 18$ years; primary TKR or THR performed; thrombosis prevention therapy - $10 \mathrm{mg}$ rivaroxaban OD; informed voluntary consent. The exclusion criteria were: atrial fibrillation with anticoagulant therapy; hemorrhagic diathesis; acute intracranial disease or hemorrhagic stroke recorded in the past three months; gastrointestinal bleeding, hematuria, peptic ulcer or duodenal ulcer recorded in the last 6 months; severe liver disease; liver transaminases (GPT and GOT) $\geq 2$ upper limits of the norm in the last month; severe renal impairment (CK $<30 \mathrm{ml} / \mathrm{min})$; advanced stage of cancer; pregnancy, lactation; age $<18$ years.

Sixty-five persons participated in the study, 19 THR patients (29.2\%) and 46 TKR patients (70.8\%). They were 48 (73.8\%) women and 17 (26.2\%) men aged 24 to 83 years (mean age $-59 \pm 12$ years). Following the instructions detailing the use of the medicine for the purposes of post-surgery thrombosis prevention, the patients took $10 \mathrm{mg}$ rivaroxaban once a day. THR patietns received the medicine for 35 days, TKR patients - for 14 days [14].

We purified DNA from the patients' venous blood. For the purposes of genotyping, the blood was collected into $4 \mathrm{ml}$ Vacuette $^{\circledR}$ vacuum tubes with EDTA-K3 anticoagulant. Real-time polymerase chain reaction (PCR) allowed genotyping $A B C B 1$ 3435C>T (rs1045642) and CYP3A5 6986A>G (rs776746) polymorphisms; we used the CFX96 Touch $^{\mathrm{TM}}$ Real-Time PCR Detection System DNA amplifier (Bio-Rad Laboratories, Inc.; USA) at Research and Development center of the Russian Medical Academy of Continuous Professional Education of the Ministry of Health of Russia.

PT was the indicator reflecting the rivaroxaban's pharmacodynamic properties; to learn it, we collected venous blood of the patients on the 5th day of their anticoagulation therapy, 1 hour before they took the medicine ( $\mathrm{PT}_{1}$ ) and 3 hours after $\left(\mathrm{PT}_{2}\right)$, into $2.7 \mathrm{ml} \mathrm{BD}$ Vacutainer ${ }^{\circledast}$ vacuum tubes with $3.2 \%$ sodium citrate. PT was determined manually, using Tekhplastintest (Tekhnologiya-Standard; Russia) in accordance with the manufacturer's instructions

The formula $\% \triangle \mathrm{PT}=\left(\mathrm{PT}_{2}-\mathrm{PT}_{1}\right) / \mathrm{PT}_{1} \times 100 \%$ allowed finding the differences between PT values through calculating $\% \triangle \mathrm{PT}$, which governed the division of patients into two $\% \triangle \mathrm{PT}$ groups: 1) patients with $\% \triangle \mathrm{PT} \leq 0 ; 2)$ patients with $\% \triangle \mathrm{PT}>0$.

The studied polymorphism genotypes frequency distribution was tested for compliance with the Hardy-Weinberg equilibrium using an online calculator [15]. To determine the difference between the groups as conditioned by the impact of $A B C B 1$ $3435 C>T$ (rs1045642) and CYP3A5 6986A>G (rs776746) polymorphisms, we ran the chi-square test for independence. PASW Statistics 18 (2009) software was used to process the results.

\section{RESULTS}

Based on the $A B C B 1$ 3435C $>T$ (rs1045642) polymorphism genotype, the patients were divided into 3 groups: 1) 3435 CC genotype, $n=17$ (26.2\%); 2) 3435CT genotype, $n=27$ (41.5\%); 3) 3435T genotype, $n=21$ (32.3\%). As for the CYP3A5 6986A>G (rs776746) polymorphism genotypes, we found 7 patients (10.8\%) with 6986AG genotype (10.8\%) and 58 patients $(89.2 \%)$ with $6986 \mathrm{GG}$ genotype (Table 1).

The ABCB1 3435C>T (rs1045642) and CYP3A5 6986A>G polymorphism genotypes distributions were within the HardyWeinberg equilibrium, $\left(\chi^{2}=1.79 ; p=0.409\right.$ and $\chi^{2}=0.21$; $p=0.9$, respectively). 
Among the patients participating in the study, the mean PT value (measured 1 hour before administration of rivaroxaban) was $15.5 \pm 4.1$ seconds, and the mean $\mathrm{PT}_{2}$ value (measured 3 hours after administration of rivaroxaban) was $19.1 \pm 3.2$ seconds. Table 2 shows other mean PT values through the lens of their dependence on the $A B C B 13435 C>T$ ( $r$ 1045642) and CYP3A5 6986A>G (rs776746) polymorphism genotypes.

Case-wise analysis of the PT variability revealed 7 patients $(10.8 \%)$ that had a paradoxical reaction, i.e. after administration of rivaroxaban the PT in them either grew smaller or did not change (\% $\triangle \mathrm{PT} \leq 0)$. In the remaining 58 patients (89.2\%) rivaroxaban made the $\mathrm{PT}$ greater, as expected (\% $\triangle \mathrm{PT}>0)$. 6 patients (85.7\%) were carrying the ABCB1 3435CT genotype and none - the ABCB1 3435T genotype in the group with $\% \triangle P T \leq 0$. The chi-square test for independence revealed a statistically significant difference between \% $\triangle \mathrm{PT}$ groups as conditioned by the distribution of the ABCB1 3435C>T (rs1045642) polymorphism genotypes $\left(\chi^{2}=6.64 ; p=0.027\right.$ ) (Table 3 ).

Patients with the ABCB1 3435CT genotype contributed the most to the difference between $\% \triangle \mathrm{PT}$ groups. Table 4 presents "manual" determination of reliability of differences in the set of frequencies, which allows seeing the reasons behind the main difference.

As for the CYP3A5 6986A>G (rs776746) polymorphism genotypes, there were no significant differences in their distribution among $\% \triangle P T$ groups $\left(\chi^{2}=0.101 ; p=1.0\right)$ (Table 5).

\section{DISCUSSION}

Drugs as P-gp substrates are widely used in the routine clinical practice, which is why studying the effect $A B C B 1$ gene polymorphisms have on pharmacodynamic and pharmacokinetic qualities of medications is a matter of great interest.

Today, many researchers investigate the impact of $A B C B 1$ gene polymorphisms on the pharmacodynamic properties of various medicines. One of the efforts was aimed at studying the relationship between $A B C B 13435 \mathrm{C}>\mathrm{T}$ polymorphism and response to antiretroviral therapy in HIV-1 patients $(n=123)$ that received efavirenz or nelfinavir [16]. The authors of that research found that patients with the 3435T allele respond to antiretroviral therapy better. Another work revealed no link between the ABCB1 3435C > T (rs1045642) polymorphism and virological, immunological responses to antiretroviral therapy [17].

P-gp also transports antiepileptic drugs [18]. Genotyping epilepsy patients $(n=315)$ by the ABCB1 3435C > T ( $r$ 1045642) polymorphism, the researchers discovered that those resistant to antiepileptic pharmacotherapy are more likely to carry the ABCB1 3435CC genotype as opposed to the patients whose response to such therapy was positive [19].

CYP3A5 gene polymorphism can contribute to the variability of CYP3A5 substrates clearance. Studying the effect CYP3A5 expression has on the pharmacological response of statins, the researchers have shown that lovastatin, simvastatin and atorvastatin are significantly less effective in CYP3A5 expressors than in non-expressors [20].

In the context of our work, which also addressed the impact of $A B C B 1$ and $C Y P 3 A 5$ genes polymorphisms on the pharmacodynamic properties of a drug - rivaroxaban, in our case, - we have revealed a statistically significant difference in distribution of $A B C B 13435 C>T$ (rs1045642) polymorphism genotypes between $\% \triangle \mathrm{PT}$ groups, one with $\% \triangle \mathrm{PT} \leq 0$ and another with $\% \triangle P T>0$. The difference mainly originates with

Table 1. Distribution of $A B C B 13435 C>T$ (rs1045642) and CYP3A5 6986A>G (rs776746) polymorphisms genotypes in THR and TKR patients receiving rivaroxaban

\begin{tabular}{|c|c|c|c|}
\hline \multirow{2}{*}{ Polymorphisms } & \multirow{2}{*}{ Genotype } & absolute & relative, \% \\
\cline { 2 - 4 } & & 17 & 26.2 \\
\hline \multirow{3}{*}{$A B C B 13435 \mathrm{C}>\mathrm{T}(\mathrm{rs} 1045642)$} & $A B C B 13435 \mathrm{CC}$ & 27 & 41.5 \\
\cline { 2 - 4 } & $A B C B 13435 \mathrm{CT}$ & 21 & 32.3 \\
\cline { 2 - 4 } & $A B C B 13435 \mathrm{~T}$ & 7 & 10.8 \\
\hline \multirow{2}{*}{ CYP3A5 6986A>G (rs776746) } & CYP3A56986AG & 58 & 89.2 \\
\cline { 2 - 4 } & CYP3A56986GG & 5 & \\
\hline
\end{tabular}

Table 2. Mean PT values by group and as conditioned by the $A B C B 13435 C>T$ (rs1045642) and CYP3A5 6986A>G (rs776746) polymorphism genotypes in THR and TKR patients receiving rivaroxaban

\begin{tabular}{|l|c|c|c|c|c|}
\hline & Mean $\mathrm{PT}_{1}, \mathrm{~s}$ & $\mathrm{Mean}_{\mathrm{PT}}, \mathrm{s}$ & $p$ & Mean $\triangle \mathrm{PT}, \mathrm{s}$ & $\mathrm{Mean} \% \Delta \mathrm{PT}, \%$ \\
\hline Participating patients $(n=65)$ & $15.5 \pm 4.1$ & $19.1 \pm 3.2$ & $\begin{array}{c}t=9.185 \\
p=2.7 \times 10^{-13}\end{array}$ & $3.6 \pm 4.9$ & $27.4 \pm 26.3$ \\
\hline ABCB13435CC & $14.8 \pm 2.1$ & $19.8 \pm 3.7$ & $\begin{array}{c}t=5.48 \\
p=5.03 \times 10^{-5}\end{array}$ & $4.95 \pm 3.3$ & $34.7 \pm 24.5$ \\
\hline ABCB13435CT & $16.0 \pm 5.7$ & $18.4 \pm 3.0$ & $\begin{array}{c}t=4.074 \\
p=3.85 \times 10^{-4}\end{array}$ & $2.4 \pm 6.8$ & $22.8 \pm 32.9$ \\
\hline ABCB13435TT & $15.5 \pm 2.8$ & $19.5 \pm 2.7$ & $\begin{array}{c}t=6.652 \\
p=1.77 \times 10^{-6}\end{array}$ & $4.02 \pm 2.2$ & $27.3 \pm 15.8$ \\
\hline CYP3A56986AG & $14.3 \pm 1.9$ & $20.6 \pm 3.1$ & $\begin{array}{c}t=5.358 \\
p=0.002\end{array}$ & $6.3 \pm 4.2$ & $47.3 \pm 34.8$ \\
\hline CYP3A56986GG & $15.7 \pm 4.3$ & $18.9 \pm 3.1$ & $\begin{array}{c}t=7.798 \\
p=1.49 \times 10^{-10}\end{array}$ & $3.2 \pm 4.95$ & $25.0 \pm 24.3$ \\
\hline
\end{tabular}

Table 3. Distribution of $A B C B 13435 \mathrm{C}>\mathrm{T}$ (rs1045642) polymorphism genotypes, \% $\triangle \mathrm{PT}$ groups, THR and TKR patients receiving rivaroxaban $(n=65)^{\star}$

\begin{tabular}{|l|c|c|}
\hline & $\% \triangle \mathrm{PT} \leq 0$ & $\% \Delta \mathrm{PT}>0$ \\
\hline$A B C B 13435 \mathrm{CC}$ & $1(14.3 \%)$ & $16(27.6 \%)$ \\
\hline$A B C B 13435 \mathrm{CT}$ & $6(85.7 \%)$ & $21(36.2 \%)$ \\
\hline$A B C B 13435 \mathrm{TT}$ & $0(0 \%)$ & $21(36.2 \%)$ \\
\hline
\end{tabular}

Note: ${ }^{*} \chi^{2}=6.64 ; p=0.027$. 
Table 4. Determination of significance of differences between observed and expected distribution of ABCB1 3435C>T (rs1045642) polymorphism genotypes, $\% \triangle \mathrm{PT}$ groups

\begin{tabular}{|c|c|c|c|}
\hline \multicolumn{4}{|c|}{ Observed genotypes distribution, $\% \Delta \mathrm{PT}$ groups } \\
\hline & $\% \Delta \mathrm{PT} \leq 0$ & $\% \Delta \mathrm{PT}>0$ & Total \\
\hline$A B C B 13435 C C$ & 1 & 16 & 17 \\
\hline$A B C B 13435 C T$ & 6 & 21 & 27 \\
\hline ABCB1 3435TT & 0 & 21 & 21 \\
\hline Total & 7 & 58 & 65 \\
\hline \multicolumn{4}{|c|}{ Expected genotypes distribution, $\% \Delta \mathrm{PT}$ groups } \\
\hline & $\% \Delta \mathrm{PT} \leq 0$ & $\% \Delta \mathrm{PT}>0$ & Total \\
\hline$A B C B 13435 C C$ & 2 & 15 & 17 \\
\hline$A B C B 13435 C T$ & 3 & 24 & 27 \\
\hline ABCB1 3435Tा & 2 & 19 & 21 \\
\hline Total & 7 & 58 & 65 \\
\hline \multicolumn{4}{|c|}{ Significant difference between observed and expected genotypes distribution } \\
\hline & $\% \triangle \mathrm{PT} \leq 0$ & $\% \Delta \mathrm{PT}>0$ & Total \\
\hline$A B C B 13435 C C$ & 0.50 & 0.07 & 0.57 \\
\hline ABCB1 3435CT & 3.00 & 0.38 & 3.38 \\
\hline ABCB1 3435TT & 2.00 & 0.21 & 2.21 \\
\hline Total & 5.50 & 0.66 & 6.16 \\
\hline
\end{tabular}

Table 5. Distribution of CYP3A5 6986A $>\mathrm{G}$ (rs776746) polymorphism genotypes, $\% \triangle P T$, THR and TKR patients receiving rivaroxaban $(n=65)^{\star}$

\begin{tabular}{|l|l|l|}
\hline & $\% \Delta \mathrm{PT} \leq 0$ & $\% \triangle \mathrm{PT}>0$ \\
\hline CYP3A5 6986AG & $1(14.3 \%)$ & $6(10.3 \%)$ \\
\hline CYP3A5 6986GG & $6(85.7 \%)$ & $52(89.7 \%)$ \\
\hline
\end{tabular}

Note: ${ }^{*} \chi^{2}=0.101 ; p=1.0$

the patients carrying the ABCB1 3435CT genotype (85.7\%) that belong to the $\% \triangle \mathrm{PT} \leq 0$ group; this may point to the necessity to adjust the dose for such people, since the standard dose of rivaroxaban may have no clinical effect in them.

The majority (89.2\%) of patients participating in our study had the CYP3A5 6986GG genotype; the CYP3A5 isoenzyme was not fully expressed in their bodies. As for the distribution of CYP3A5 6986A>G (rs776746) polymorphism genotypes in the $\% \triangle \mathrm{PT}$ groups, the difference between them was insignificant, which presumably signals of the role of CYP3A5 isoenzyme in rivaroxaban pharmacokinetics being inferior to that of the P-gp membrane transporter.

Considering the discovered effect $A B C B 1$ 3435C>T (rs1045642) polymorphism has on \% $\triangle \mathrm{PT}$ under the influence of rivaroxaban, we believe it is important to research not only pharmacodynamics, but also pharmacokinetics of rivaroxaban in patients with different genotypes.

\section{CONCLUSIONS}

We discovered that $A B C B 13435 \mathrm{C}>\mathrm{T}$ (rs1045642) polymorphism has a statistically significant effect on PT variance in THR and TKR patients taking rivaroxaban to prevent thrombosis. There was found no statistically significant dependence of $\% \triangle P T$ on CYP3A5 6986A>G (rs776746) polymorphism. We believe it is necessary to study both pharmacodynamics and pharmacokinetics of rivaroxaban in patients with different genotypes.

The funding organization played no role in the study design, collection, analysis and interpretation of data, writing of the report, or decision to submit the report for publication.

\section{References}

1. Geerts WH, Heit JA, Clagett GP, Pineo GF, Colwell CW, Anderson FA Jr et al. Prevention of venous thromboembolism. Chest. 2001; 119 (1): 132-75.

2. Agnelli G. Prevention of venous thromboembolism in surgical patients. Circulation. 2004; 110 (24 Suppl 1): 4-12.

3. Kavalerskij GM, Sereda AP, Murylev VJu, Rukin JaA, Gavrilov AV, Arhipov IV, i dr. 2D-planirovanie jendoprotezirovanija tazobedrennogo sustava. Travmatologija i ortopedija Rossii. 2015; 4 (78): 95-102.

4. New Drug Application (NDA) of the Federal Food, Drug, and Cosmetic Act (FDCA) for Xarelto ${ }^{\circledast}$ (rivaroxaban) 10 mg immediate release Tablets, for the prophylaxis of deep vein thrombosis and pulmonary embolism in patients undergoing: hip replacement surgery or knee replacement surgery [Internet]. 2008 July [cited
2018 Aug 1]. Available from: https://www.accessdata.fda.gov/ drugsatfda_docs/appletter/2011/022406s000ltr.pdf.

5. European Medicines Agency. Doc.Ref.: EMEA/543519/2008 CHMP assessment report for Xarelto. [Internet]. 2008 [cited 2018 Aug 1]. Available from: http://www.ema.europa.eu/docs/ en_GB/document_library/EPAR_-_Public_assessment_report/ human/000944/WC500057122.pdf.

6. Fromm MF. Importance of P-glycoprotein at blood-tissue barriers. Trends Pharmacol Sci. 2004; 25 (8): 423-9.

7. GeneCards: The Human Gene Database. ABCB1 Gene [Internet]. [cited 2018 Aug 1]. Available from: https://www.genecards.org/ cgi-bin/carddisp.pl?gene=ABCB1.

8. Wang D, Johnson AD, Papp AC, Kroetz DL, Sadée W. Multidrug resistance polypeptide 1 (MDR1, ABCB1) variant 3435C>T affects 
mRNA stability. Pharmacogenet Genomics. 2005; 15 (10): 693704.

9. Lamba J, Hebert JM, Schuetz EG, Klein TE, Altman RB. PharmGKB summary: very important pharmacogene information for CYP3A5. Pharmacogenet Genomics. 2012; 22 (7): 555-8.

10. Eriksson $\mathrm{Bl}$, Borris LC, Friedman RJ, Haas S, Huisman MV, Kakkar AK et al. Rivaroxaban versus enoxaparin for thromboprophylaxis after hip arthroplasty. N Engl J Med. 2008; 358 (26): 2765-75.

11. Kakkar AK, Brenner B, Dahl OE, Eriksson BI, Mouret P, Muntz J et al. Extended duration rivaroxaban versus short-term enoxaparin for the prevention of venous thromboembolism after total hip arthroplasty: a double-blind, randomised controlled trial. Lancet. 2008; 372 (9632): 31-9.

12. Lassen MR, Ageno W, Borris LC, Lieberman JR, Rosencher N, Bandel $\mathrm{TJ}$ et al. Rivaroxaban versus enoxaparin for thromboprophylaxis after total knee arthroplasty. N Engl J Med. 2008; 358 (26): 2776-86.

13. Turpie AG, Lassen MR, Davidson BL, Bauer KA, Gent M, Kwong LM et al. Rivaroxaban versus enoxaparin for thromboprophylaxis after total knee arthroplasty (RECORD4): a randomised trial. Lancet. 2009; 373 (9676): 1673-80.

14. Instrukcija po medicinskomu primeneniju lekarstvennogo sredstva
Ksarelto ${ }^{\oplus} v$ Rossijskoj Federacii. Registracionnyj nomer: LSR009820/09.

15. Online Encyclopedia for Genetic Epidemiology studies. HardyWeinberg equilibrium calculator [Internet]. [cited 2018 Dec 12]. Available from: http://www.oege.org/software/hwe-mr-calc.shtml

16. Fellay J, Marzolini C, Meaden ER, Back DJ, Buclin T, Chave JP et al. Response to antiretroviral treatment in HIV-1-infected individuals with allelic variants of the multidrug resistance transporter 1: a pharmacogenetics study. Lancet. 2002; 359 (9300): 30-6.

17. Nasi M, Borghi V, Pinti M, Bellodi C, Lugli E, Maffei S. MDR1 C3435T genetic polymorphism does not influence the response to antiretroviral therapy in drug-naive HIV-positive patients. AIDS. 2003; 17 (11): 1696-8.

18. Löscher W., Potschka $H$. Role of multidrug transporters in pharmacoresistance to antiepileptic drugs. J Pharmacol Exp Ther. 2002; 301 (1): 7-14.

19. Siddiqui A, Kerb R, Weale ME, Brinkmann U, Smith A, Goldstein DB. Association of multidrug resistance in epilepsy with a polymorphism in the drug-transporter gene ABCB1. N Engl J Med. 2003; 348 (15): 1442-8.

20. Kivistö KT, Niemi M, Schaeffeler E, Pitkälä K, Tilvis R, Fromm MF Lipid-lowering response to statins is affected by CYP3A5 polymorphism. Pharmacogenetics. 2004; 14 (8): 523-5.

\section{Литература}

1. Geerts WH, Heit JA, Clagett GP, Pineo GF, Colwell CW, Anderson FA Jr et al. Prevention of venous thromboembolism. Chest. 2001; 119 (1): 132-75.

2. Agnelli G. Prevention of venous thromboembolism in surgical patients. Circulation. 2004; 110 (24 Suppl 1): 4-12.

3. Кавалерский Г. М., Середа А. П., Мурылев В. Ю., Рукин Я. А. Гаврилов А. В., Архипов И. В. и др. 2D-планирование эндопротезирования тазобедренного сустава. Травматология и ортопедия России. 2015; 4 (78): 95-102.

4. New Drug Application (NDA) of the Federal Food, Drug, and Cosmetic Act (FDCA) for Xarelto ${ }^{\circledR}$ (rivaroxaban) $10 \mathrm{mg}$ immediate release Tablets, for the prophylaxis of deep vein thrombosis and pulmonary embolism in patients undergoing: hip replacement surgery or knee replacement surgery [Internet]. 2008 July [cited 2018 Aug 1]. Available from: https://www.accessdata.fda.gov/ drugsatfda_docs/appletter/2011/022406s000ltr.pdf.

5. European Medicines Agency. Doc.Ref.: EMEA/543519/2008. CHMP assessment report for Xarelto. [Internet]. 2008 [cited 2018 Aug 1]. Available from: http://www.ema.europa.eu/docs/ en_GB/document_library/EPAR_-_Public_assessment_report/ human/000944/WC500057122.pdf.

6. Fromm MF. Importance of P-glycoprotein at blood-tissue barriers. Trends Pharmacol Sci. 2004; 25 (8): 423-9.

7. GeneCards: The Human Gene Database. ABCB1 Gene [Internet] [cited 2018 Aug 1]. Available from: https://www.genecards.org/ cgi-bin/carddisp. pl?gene=ABCB1

8. Wang D, Johnson AD, Papp AC, Kroetz DL, Sadée W. Multidrug resistance polypeptide 1 (MDR1, ABCB1) variant 3435C>T affects mRNA stability. Pharmacogenet Genomics. 2005; 15 (10): 693704.

9. Lamba J, Hebert JM, Schuetz EG, Klein TE, Altman RB. PharmGKB summary: very important pharmacogene information for CYP3A5. Pharmacogenet Genomics. 2012; 22 (7): 555-8.

10. Eriksson $\mathrm{BI}$, Borris LC, Friedman RJ, Haas S, Huisman MV, Kakkar AK et al. Rivaroxaban versus enoxaparin for thromboprophylaxis after hip arthroplasty. N Engl J Med. 2008; 358 (26): 2765-75
11. Kakkar AK, Brenner B, Dahl OE, Eriksson BI, Mouret P, Muntz J et al. Extended duration rivaroxaban versus short-term enoxaparin for the prevention of venous thromboembolism after total hip arthroplasty: a double-blind, randomised controlled trial. Lancet. 2008; 372 (9632): 31-9.

12. Lassen MR, Ageno W, Borris LC, Lieberman JR, Rosencher N, Bandel TJ et al. Rivaroxaban versus enoxaparin for thromboprophylaxis after total knee arthroplasty. N Engl J Med. 2008; 358 (26): 2776-86.

13. Turpie AG, Lassen MR, Davidson BL, Bauer KA, Gent M, Kwong LM et al. Rivaroxaban versus enoxaparin for thromboprophylaxis after total knee arthroplasty (RECORD4): a randomised trial. Lancet. 2009; 373 (9676): 1673-80.

14. Инструкция по медицинскому применению лекарственного средства Ксарелто ${ }^{\circledR}$ В Российской Федерации Регистрационный номер: ЛСР-009820/09.

15. Online Encyclopedia for Genetic Epidemiology studies. HardyWeinberg equilibrium calculator [Internet]. [cited 2018 Dec 12]. Available from: http://www.oege.org/software/hwe-mr-calc.shtml

16. Fellay J, Marzolini C, Meaden ER, Back DJ, Buclin T, Chave JP et al. Response to antiretroviral treatment in HIV-1-infected individuals with allelic variants of the multidrug resistance transporter 1: a pharmacogenetics study. Lancet. 2002; 359 (9300): 30-6.

17. Nasi M, Borghi V, Pinti M, Bellodi C, Lugli E, Maffei S. MDR1 C3435T genetic polymorphism does not influence the response to antiretroviral therapy in drug-naive HIV-positive patients. AIDS. 2003; 17 (11): 1696-8.

18. Löscher W., Potschka $\mathrm{H}$. Role of multidrug transporters in pharmacoresistance to antiepileptic drugs. J Pharmacol Exp Ther. 2002; 301 (1): 7-14.

19. Siddiqui A, Kerb R, Weale ME, Brinkmann U, Smith A, Goldstein DB. Association of multidrug resistance in epilepsy with a polymorphism in the drug-transporter gene ABCB1. N Engl J Med. 2003; 348 (15): 1442-8.

20. Kivistö KT, Niemi M, Schaeffeler E, Pitkälä K, Tilvis R, Fromm MF. Lipid-lowering response to statins is affected by CYP3A5 polymorphism. Pharmacogenetics. 2004; 14 (8): 523-5. 